\title{
DE CURAÇAOSCHE BEGROOTING VOOR 1924 \\ DOOR
}

\author{
Mr. B. DE. GAAY FORTMAN
}

De belangstelling voor de Curaçaosche begrooting vermindert.

Dien indruk krijgt men misschien niet aanstonds bij het naslaan der Handelingen. In de Tweede Kamer is nu wellicht meer over dit onderwerp gesproken dan verleden jaar, vooral als men het onderwerp der gebeurtenissen van 17 Juli 1922 uitschakelt. En in de Eerste Kamer, waar toen bij de openbare beraadslaging geen woord over $\mathrm{Cu}$ raçao gezegd werd, hield thans Curaçao's warme vriend, de heer Van Kol, eene rede, waarin wel is waar al te zeer groote lijnen ontbraken, doch die toch de lust ons bekruipen doet, dien afgevaardigde ook eens aan het werk te zien. Maar die redevoeringen werden gehouden, als men de persverslagen gelooven mag, voor wat men in een kerk noemen zou „,stoelen en banken.” En ook zag de Minister van Koloniën kans in minder dan twee kolommen druks het eenige Eerste-Kamer-lid, dat het woord gevoerd had te beantwoorden, en met ongeveer evenveel woorden werden de vier sprekers aan de overzijde van het Binnenhof, de hh. Yzerman, Feber, Deckers en Mej. Van Dorp tevreden gesteld.

En van de Regeering moet het ten slotte toch komen. Wat aanstonds opvalt is het verschil in inzicht in den algemeenen toestand der kolonie hier en ginds.

Was in de afdeelingen van den Kolonialen Raad door „de meeste leden" als hun oordeel uitgesproken, dat de tegenwoordige huishouding nimmer zou leiden tot eene sluitende begrooting, de Minister heeft tegenover de klachten van den heer Van Kol er op gewezen, dat de vooruit- 
gang van Curaçao zoodanig is, „,dat het budget van landsuitgaven vermoedelijk spoedig sluitend zal zijn." Dit moest den indruk dier klachten verzachten. Maar hier staan andere dingen tegenover, die zwaar wegen, ook al wordt het in uitzicht gestelde ,in korten tijd" bereikt. Vooreerst dit, dat de materieele vooruitgang feitelijk alleen het hoofdeiland betreft, en de toestand der andere eilanden, met name die der bovenwindsche eilanden, allerbedroevendst is. En dan: hoe zal die sluitende begrooting in den thans gevolgden weg bereikt worden? Door bezuiniging op de uitgaven en versterking van de inkomsten. Dat is in theorie voortreffelijk, omdat dit mes van twee kanten snijdt. Maar de Koloniale Raad zegt ervan, dat het streven om de inkomsten der kolonie te verhoogen „niet evenredig" gepaard gaat met een veel noodzakelijker streven tot bezuiniging. En in de Tweede Kamer is gezegd, wat den Kolonialen Raad als muziek in de ooren zal geklonken hebben, dat de grens aan eene opvoering van den belastingdruk gesteld, op Curaçao, waar slechts een klein deel van de bevolking uit vermogenden of uit menschen met een middenstandsinkomen bestaat, zeer spoedig bereikt zal zijn. Ook over den aard der bezuinigingen is gesproken. In het Voorloopig Verslag der Tweede Kamer was gezegd, dat de bezuiniging voor een niet gering deel verkregen is door het uitstellen van noodzakelijke uitgaven, hetgeen op den duur tot een zeer onbevredigend resultaat, verhooging van uitgaven in plaats van besparing, zal leiden. „Alleen de bevordering van de totstandkoming van een gezonden economischen toestand," zoo heet het, ,kan tot een reëele en blijvende bezuiniging voeren." De Minister heeft dit beaamd en op betere tijden gehoopt. Ook daarom lijkt het uitzicht op eene sluitende begrooting voorloopig niet veel meer dan een vergezicht, ook al omdat zij, die den eisch van bezuiniging in het algemeen toegaven- en wie zou dat niet gedaan hebben toch weinig opbouwende critiek geleverd hebben door aan te geven waar en hoe dan welbezuinigd zou kunnen worden.

Alvorens van het bezuinigingsvraagstuk af te stappen, zij het mij vergund nog eene opmerking te maken ter 
weerlegging van het verwijt, alsof gouverneur Helfrich de dure gouverneur geweest is en zijn opvolger een bezuiniger bij uitnemendheid is. Men leze nog eens de rede van eerstgenoemde bij de aanvaarding van zijn bewind, waarin uitdrukkelijk de noodzakelijkheid van vermindering der bijdragen van het moederland is naar voren gebracht. De gewoonlijk als „,belastingherzienings-commissie” aangeduide commissie had ook ten doel bezuinigingsmaatregelen te ontwerpen. Verschillende harer voorstellen zijn uitgevoerd. En in het algemeen kan men zeggen, dat het streven van den gouverneur is geweest: zuinigheid en bezuiniging, die de wijsheid niet konden bedriegen. Behalve de opschorting der uitvoering van verschillende, niet dringend noodzakelijke, werken moet genoemd de inkrimping van het ambtenarencorps. De opheffing van den landbouwkundigen dienst op de benedenwindsche eilanden is door gouverneur Helfrich in uitzicht gesteld, en naar wat van zijne politie-voorstellen is bekend geworden mag ook daarin eene belangrijke bezuiniging voor de kolonie gezien worden.

De behandeling der begrooting door den Kolonialen Raad is eigenlijk eene wat wonderlijke geschiedenis geweest. Het Voorloopig Verslag roerde tal van belangrijke vraagstukken aan; om enkele te noemen: de verbinding met de bovenwindsche eilanden, den economischen toestand van dezen, de politie, de schutterij, den draadloozen dienst, het onderwijs enz. Op de kostbaarheid van den Openbaren Gezondsheidsdienst, den Mijnbouwkundigendienst en de plannen tot Watervoorziening werd gewezen en de wensch uitgesproken, dat deze uitgaven met die voor Onderwijs binnenkort ,in een gesplitste begrooting” voor rekening van het Moederland zouden komen. De heer Maduro voegde hier later nog bij de kosten van de verbinding tusschen de eilanden, die volgens hem op een lijn met het traktement en pensioen van den gouverneur en met de uitgaven voor zee- en landmacht zouden te stellen zijn, eene redeneering, die moeilijk onjuist te noemen is.

Maar hiermee is al het belangrijkste van de openbare behandeling naar voren gebracht. Immers deze is begon- 
nen met eene redevoering van den ,tijdelijken voorzitter”, die in wat hoogdravende taal den buitenstaander den indruk geeft, dat er buiten de officieele gedachtenwisseling om achter de schermen een en ander is beklonken, waardoor van eene verdere behandeling der begrooting eigenlijk geen sprake meer behoefde te zijn. En daarvan kan dan ook moeilijk gesproken worden. Behalve de heer Maduro wiens beschouwingen ik reeds weergaf, trad alleen het raadslid De Veer Abrahamsz naar voren met twee vragen, die beter bij de ,,artikelen" waren gedaan, doch tot eene artikelsgewijze behandeling kwam het niet, want alles ging er zonder beraadslaging en stemming door. Voorwaar, het presidiaal interregnum kan moeilijk geacht worden te hebben bijgedragen tot versteviging van het „parlementaire stelsel"' in Curaçao!

Op het ministerieel departement onderging de voorloopig vastgestelde begrooting twee belangrijke wijzigingen. De raming der uitgaven werd door schrappning van eenige posten, w. o. $f 12000$. - voor het bijzonder onderwijs en $f 27.000$. - voor nieuwe werken, verlaagd met $f$ 43.000.- ; de ontvangsten werden met $f 130.000$,- - verhoogd als gevolg van eene voorgenomen herziening van verschillende heffingen. De bijdrage van het moederland daalde op deze wijze van $f$ 730.000, - tot $f$ 557.000.-

In de tweede plaats vindt men op de begrooting, zooals zij bij de Staten-Generaal is ingediend, een geheel nieuwe post voor „memorie” uitgetrokken, en aldus omschreven: „Uitgaven in het belang van de hieronder omschreven voorzieningen voor eens, die uitsluitend ter hand mogen worden genomen voorzoover door beperking van uitgaven op andere onderdeelen van de begrooting als anderszins de bekostiging daarvan kan plaats vinden binnen de grenzen van de beschikbaar gestelde Rijksbijdrage aan de koloniale geldmiddelen." Men zou deze post kunnen noemen het resultaat van de interpellatie - Marchant, die ik verleden jaar in mijn opstel over West-Indische Koloniale autonomie in dit tijdschrift uitvoerig besproken heb. De Minister heeft getracht aldus de in de Tweede Kamer tegen zijn voornemen, om te trachten den West-Indischen 
gouverneurs meer vrijheid van handelen te geven wat aangaat de uitvoering der begrooting, geuite bezwaren van verzwakking van het toezicht der Staten-Generaal op het begrootingsbeheer te ondervangen.

Een der belangrijke onderwerpen, die in de StatenGeneraal ter sprake zijn gekomen, is de havenverbetering te Willemstad. Het ten vorigen jare toegezegde overleg tusschen Minister en Gouverneur heeft ten gevolge gehad, dat laatstgenoemde als het belangrijkste naar voren bracht de watervoorziening voor de schepen, daarna het leggen van twee meerboeien in het Scholtegat en ten slotte de verbetering van de De Ruyterkade, waardoor de capaciteit van de haven ten aanzien van lig- en losplaatsen ,eenigszins”, n.l. met een ligplaats voor één schoener, zal worden vergroot. Alleen de beide laatste maatregelen betreffen de eigenlijke havenverbetering. De heer IJzerman wees er in de Tweede Kamer terecht op, dat dit moeilijk voldoende kan worden geacht in verband met de snelle ontwikkeling van het havenverkeer. Dit kamerlid gaf daaromtrent eenige cijfers, die voor uitbreiding vatbaar zijn, en hier volledig mogen volgen:

\begin{tabular}{c|c|c|c|c}
\hline \hline Jaar. & Stoomsch. & Inhoud in $M^{*}$. & Zeilsch. & Inhoud in M$^{*}$ \\
\hline & & & & \\
1912 & 410 & 2.503 .409 & 1018 & 119.661 \\
1913 & 415 & 2.829 .601 & 1071 & 122.384 \\
1914 & 383 & 2.697 .972 & 1068 & 125.078 \\
1915 & 332 & 2.111 .083 & 1024 & 128.590 \\
1916 & 314 & 1.992 .645 & 1325 & 155.503 \\
1917 & 317 & 1.030 .114 & 1505 & 169.830 \\
1918 & 248 & 680.753 & 1497 & 198.336 \\
1919 & 384 & 1.336 .547 & 1294 & 193.167 \\
1920 & 578 & 3.560 .578 & 1066 & 281.108 \\
1921 & 890 & 3.958 .829 & 1172 & 228.968 \\
1922 & 1182 & 5.308 .487 & 1241 & 169.952 \\
1923 & 1480 & 7.467 .413 & 1276 & 296.606
\end{tabular}

Dat zijn toch werkelijk enorme cijfers, en met eenige bezorgdheid vraagt men zich af, waar het heen moet, 
wanneer de outillage van de haven daarmee geen gelijkentred houdt. Gewezen werd op de voorstellen in het belang der havenontwikkeling van den oud-Gouverneur Helfrich. Het is trouwens eigenaardig hoe dikwijls die naam genoemd werd: het plan-Helfrich voor de economische opheffing der kolonie, de oplossing-Helfrich van de politiekwestie; er is eigenlijk geen onderwerp, in zijn tijd van beteekenis, waaraan de vorige gouverneur in den korten tijd van zijn bewind niet zijn aandacht gewijd heeft, en waaromtrent hij geen voorstellen gedaan heeft, totdat hij, zooals de heer Van Kol opmerkte, in arren moede zijn ambt neerlegde. En het ergste is, dat al die kwesties nòg kwesties zijn, of op al te radicale wijze uit de koloniale politiek verdwenen. Dit is o. a. het geval met het planHelfrich (ter economische opheffing der kolonie), dat ik destijds uitvoerig in dit tijdschrift heb aangekondigd. Er is daarvan een karikatuur gemaakt door als eenig overschot van die uitgewerkte maatregelen op de begrooting voor $1923 f$ 10.000.- uit te trekken als voorschotten voor buitengewone uitgaven ter verbetering van de veeteelt. Dit geschiedde bij amendement in den Kolonialen Raad, nadat de Gouverneur in afwijking van het oorspronkelijk plan, waarmee de Koloniale Raad zich destijds met algemeene stemmen had vereenigd, reeds niet meer dan $f 50.000$, gevraagd had.

Ook nu is dit onderwerp weer ter sprake gekomen. In de M. v. A. aan de Tweede Kamer heeft de Minister gewezen op de geringe geneigdheid tot het nemen van voorschotten voor den kleinen landbouw onder redelijke waarborgen. De heer Feber heeft dit aanvaard, maar inmiddels was in de N. R. Ct. van 26, 27 en 28 Juni 1923 in eene belangrijke briefwisseling over Curaçao gezegd, dat dit plan-Helfrich heel wat meer omvattend was en daaraan eigenlijk nog in het geheel geen uitvoering is gegeven. Trouwens men zou nu om deze zaak te kunnen beoordeelen, toch ook moeten weten, welke voorwaarden voor het verkrijgen van voorschotten zijn gesteld, en of deze niet te bezwarend waren, zooals wel beweerd is. In de Eerste Kamer heeft de heer Van Kol nog eens een lans gebroken 
voor deze zaak, en toen heeft de Minister - tot veler verwondering ongetwijfeld - gezegd, dat het plan-Helfrich voor hem nooit meer is geweest dan ,een voorstel van ondergeschikte beteekenis", en dat ook onder den genoemden Gouverneur het niet gelukt is voor den kleinen landbouw en veeteelt belangstelling te wekken. Deze verklaring moet verwondering wekken, en van tweeën één: óf de Minister was niet voldoende op de hoogte der zaak of men had hem verkeerd ingelicht. Hierop is reeds uitvoerig gewezen in een der aangehaalde artikelen in de N. R. Ct. Onder het bestuur van Gouverneur Helfrich was diens „plan" zelfs nog niet tot een begin van uitvoering gekomen door diens kort na de voorbereiding gevolgd vertrek. De lust vergaat, om er dieper op in te gaan, maar dat men de - om zoo te zeggen - laatste kans op dit gebied onbenut heeft laten voorbijgaan zal door deskundigen wel niet ontkend worden.

Op een punt speelde de Minister op zijn beurt den heer Helfrich uit tegen den heer Van Kol, toen hij diens philippica tegen de paga-terra-contracten beantwoordde met de opmerking, dat „,de Gouverneur Helfrich, die zich bijzonder met de zaak heeft beziggehouden, geëndigd is met te verklaren, dat hij geen reden vond om zich tegen het contract te verzetten."

Wat over het onderwijs gezegd is, getuigde over het algemeen niet van groote kennis van zaken. Er is gebrek aan Nederlandsche leerkrachten, zoo leest men in het Voorloopig Verslag der Tweede Kamer, en dat komt door de lage salarissen, en dit is weer te wijten aan de ",gelijkstelling," die heeft gemaakt, „dat de voor onderwijs beschikbare gelden voor een groot deel aan subsidies voor het bijzonder onderwijs worden besteed, hetgeen aan het openbaar onderwijs ten nadeel komt." Die redeneering is nu toch ten eenemale in strijd met de feiten, eenvoudig omdat er geen ,,voor onderwijs beschikbare gelden" zijn. En wie hierover met kennis van zaken zou willen oordeelen, zou in de eerste plaats moeten weten, dat volstrekt niet alleen de onderwijzerssalarissen te laag zijn, maar alle salarissen voor betrekkingen, waarvoor ambtenaren 
uit Nederland moeten uitkomen, zoodat men elders even goed als bij het onderwijs tot benoeming boven het maximum zijn toevlucht heeft moeten nemen. Niettemin heeft Mej. Van Dorp zich tot tolk van die beschouwingen gemaakt, en daarbij deze enormiteit weten te plaatsen: „Nu zeg ik niet, dat ik de subsidies voor het bijzonder onderwijs niet billijk vind. Maar het is voor Curacao niet noodig, want er was geen behoefte aan, er was niemand, die er aan dacht. Er waren een aantal goede zusterscholen, die niet om subsidies vroegen. $\mathrm{Nu}$ gaan wij de kolonie opdringen de gevolgen van den politieken strijd in Nederland." Elders ${ }^{1}$ ) is deze spreekster den weg gewezen, hoe zij zich beter op de hoogte stellen kan; het is te hopen, dat zij die aanwijzing volgt.

Maar ook de Koloniale Raad is in hare onderwijs beschouwingen over de schreef gegaan, „De meeste leden” vonden het onderwijs te duur en wilden eene goedkoopere inrichting. „Als voorbeeld werd aangehaald de Venezolaansche onderwijemothada Door woodt b. v. door jonge dames, die daar lust toe gevoelen een klasse om zich vereenigd, door het Gouvernement gesteund en het jonge volkje op eenvoudige, wellicht primitieve wijze het lezen en schrijven, optellen en aftrekken geleerd. Maar iedere Venezolaan kan lezen en schrijven en het valt op, hoevelen uit het volk couranten lezende worden aangetroffen." De Gouverneur antwoordde voorzichtig, dat hem de gegevens ontbraken, om te beoordeelen, of de aanbevolen methode zou kunnen worden gevolgd. Het stelsel was wel wat ingewikkelder, zoo werd daaraan toegevoegd, dan de mededeelingen van den Raad deden vermoeden, en tenslotte werd betwijfeld, of iedere Venezolaan wel zou kunnen lezen en schrijven ,ofschoon het lager onderwijs kosteloos is en er leerplicht bestaat." De heer Van Kol zei het leuker in de Eerste Kamer; hij betwijfelde of het onderwijs der Venezolaansche dames-amateurs navolgenswaard was, en achtte die dames ,beter geschikt voor Spaansche dansen dan voor het geven van een wetenschappelijke en moreele opvoeding aan de kinderen."

\footnotetext{
1) In het Koloniaal Weekblad van 24 April 1924.
} 
Eindelijk nog een enkel woord over de Bovenwindsche eilanden. De economische toestand is er ongunstig, en wordt er niet beter op. Het artikel van den heer V. d. Plaats in dit tijdschrift heeft èn den heer IJzerman èn den heer Deckers aanleiding tot beschouwingen gegeven. Moet inderdaad de landbouwpost, goed toegerust, daar gehandhaafd blijven. Laatstgenoemde spreker antwoordde met klem bevestigend. De Minister deed er het zwijgen toe. De heer Van Kol sprak van ,eilanden zonder natuurlijke hulpbronnen", die $f 29$.- per hoofd aan ambtenaarssalarissen kosten. En nog vóór deze begrooting was vastgesteld, had de Koloniale Raad voor 1925 al het duidelijkste antwoord gegeven, en door den heelen landbouwdienst een streep gehaald.

Dordrecht, 3 Juli 1924 